\title{
Administrative oversight: improving compliance practices
}

\author{
Aleksander Nikolaevich Varygin ${ }^{11}$, Irina Alekseevna Efremova ${ }^{1}$, Vladimir Gennadievich \\ Gromov $^{2}$, Pavel Anatolievich Matushkin ${ }^{1}$, and Anastasia Mikhailovna Shuvalova ${ }^{3}$ \\ ${ }^{1}$ Saratov State Law Academy, Department of Prosecutor's Supervision and Criminology, Saratov, \\ Russia \\ ${ }^{2}$ Saratov State University, Department of Criminal, Environmental Law and Criminology, Saratov, \\ Russia \\ ${ }^{3}$ Nizhny Novgorod Branch of the St. Petersburg Academy of the Investigative Committee of the \\ Russian Federation, Department of Criminalistics, Nizhny Novgorod, Russia
}

\begin{abstract}
The main purpose of the research is to determine the goals, objectives and functions of administrative supervision and develop proposals for improving the legislation of the Russian Federation regulating issues related to the implementation of administrative supervision. Research methods: general scientific methods (analysis and synthesis, logical methods) and private scientific methods of cognition (formally-legally, specifically-sociological etc.). Outcome: the author's version of the administrative supervision goals and objectives set out in the regulatory documents of the Russian Federation is proposed: 1. Administrative supervision is established to prevent the commission of crimes and other offences by persons. 2. The administrative supervision focuses on implementation by the internal affairs bodies of supervision over the observance by supervised persons of temporary restrictions on their rights and freedoms, as well as over the fulfillment of their duties stipulated by the related federal law; identification of violations by those under the supervision and taking measures in accordance with the law; individual preventive treatment of such persons. The novelty of the study is due to an integrated approach to the research into the goals, objectives and functions of administrative supervision and the developed proposals for improving the Russian legislation regulating issues in that area.
\end{abstract}

Keywords: administrative supervision, detention facilities, crime prevention, recidivism

\section{Introduction}

Since the early 2000s, not a very rosy picture in the field of combating crime has been shaped in our country; despite a decrease in the number of registered crimes, some of the indicators, such as the level and structure, make scientists and law enforcement officers seek new measures to combat crime and its separate types, as well as improve the existing crime prevention arrangements. First of all, this refers to recidivism, which accounts for a

${ }^{1}$ Corresponding author: van808@yandex.ru 
significant and stable share in the overall structure of crime. So, in 2014, for the first time, recidivism in the general structure accounted for more than half of all crimes $-50.7 \%$, and by 2018 it increased to $59.8 \%$. Recidivism has become significant, not only in the Russian Federation but also in foreign countries [1-3]. In this connection, in foreign countries, the problems of preventing and preventing the recurrence of crimes have repeatedly become a point at issue at the highest level. For example, in the United States, issues of oversight and control over those released from prison are often the subject of Congressional hearings [4]. With that in mind, criminal executive law and criminology experts point to the need to develop and implement a mechanism that would allow for effective supervision of persons who have served a criminal sentence imposed by the court in prison and released from them [5-7]. A similar judgment is made by foreign researchers [8-10]. Such supervision should contribute to the prevention of crimes among persons who have served a criminal sentence in correctional institutions and have an increased public danger, and to reduce possible relapse in general. In this regard, in 2011, the narrowly focused federal law No. 64-FZ "Administrative Supervision over Persons Released from Detentions Facilities" (hereinafter the law No. 64-FZ) was adopted.

Administrative supervision is established with respect to not all persons who have served their sentences in correctional institutions and released from them but in relation to persons with an increased degree of public danger (they were convicted of the most serious criminal offences and (or) and failed to prove their correction during the period of serving the sentence) because it is these persons who are most prone to committing new criminal offences, in connection with which administrative supervision is aimed at preventing their commission. The legal doctrine contains positions regarding the list of persons who have served their sentences in correctional institutions and have been released from them, in respect of whom it is necessary to establish administrative supervision.

It should be noted that the legal doctrine does not have a single position regarding the place of the investigated supervision in the legal system. The positions of scientists and researchers differ significantly, so some believe that it belongs to criminal law [11-13], others to administrative law [14], and still some others not to any of the branches of Russian law, since it acts as an intersectoral legal institution [15].

Currently, there are significant problems in the legislative regulation of administrative supervision, which is confirmed by a lot of changes made to that day in the law No. 64-FZ. Proceeding from this, it should be argued that there is a need to improve the law in terms of defining the goals, objectives and functions of administrative supervision which are fundamental legal categories that influence the effectiveness of the administrative supervision implementation.

\section{$2 \quad$ Methods}

To solve the objectives, set in the study, general scientific methods (analysis and synthesis, logical methods) and private scientific methods of cognition (formally - legal, specifically sociological etc.) were used.

\section{$3 \quad$ Results and discussion}

Objectives of administrative supervision. In contemporary science, the goal is supposed to mentally represent the desired result; it reflects the individual's aspiration for a clear positive outcome [16]. The fact that the acting subject sets certain goals for itself testifies to the awareness of its behaviour. As scientists note, the purpose is expressed in that it allows planning and contributes to a more efficient organisation of any kind of work [17]. 
The objectives are specific ways and means of achieving the set purpose, that is they are directly put forward in order to achieve the purpose, resolve the problematic situation, due to which the purposes and objectives are closely interconnected.

The Russian legislator in Art. 2 of the Federal Law No. 64-FZ formulates not only the objectives but also the specific purpose of administrative supervision, namely the protection of both state and public interests. However, the legal doctrine contains a different position regarding the purpose of administrative supervision. Thus, according to some authors, the established supervision should be considered to focus on a decrease in the level of recidivism [7]. From the standpoint of those researchers, administrative supervision provides a kind of protection of society from criminal threats. At the same time, this supervision can be used as a means of ensuring that human rights and freedoms are proclaimed in the Russian Constitution as the highest value.

We believe that the purpose of administrative supervision, first of all, is to prevent the commission of crimes and other offences by supervised persons, which leads to a decrease in the level of recidivism, among other things. Administrative supervision is aimed precisely at preventing them from re-committing crimes and other offences.

Administrative supervision objectives. Based on Article 2 of the law No. 64-FZ, the key objectives of administrative supervision are to prevent the commission of new crimes, as well as other offences, by the categories of persons specified in the law; individual preventive effect on the specified persons.

We proceed from the assumption that prevention, that is the prevention of new crimes, is the purpose of administrative supervision, and not its objective. This purpose can be achieved, firstly, by imposing administrative restrictions on the supervised persons, secondly, by the actual supervision of the internal affairs bodies over the observance of those restrictions by the indicated persons and, thirdly, by individual preventive influence on them, since it is not limited to only the actual supervision of compliance with the imposed restrictions but also includes other measures, for example, preventive conversations and other measures, that is a whole range of measures of a socio-economic, pedagogical, legal and other nature carried out for the reintegration into society of persons who have served a sentence in form of imprisonment. For example, such measures may include assistance to supervised persons in employment, housing, treatment, and involvement of them in socially beneficial activities.

It should be noted that when formulating the objectives of administrative supervision, it is necessary to take into account the fact that it does not extend criminal punishment, it is another legal institution, namely an institution to prevent the commission of new crimes by already convicted persons. It should be remembered that the considered supervision over released persons from correctional institutions is carried out not by the bodies and institutions of the penal system but the internal affairs bodies (police) representing another department of the executive power. Supervision by the internal affairs bodies over the categories of persons in question is carried out through constant monitoring of how the supervised persons comply with the restrictions imposed on them, as well as through constant monitoring of how the supervised persons perform their duties. Among other things, the bodies exercising administrative supervision influence such persons by conducting preventive conversations with them, other explanatory work, applying various measures of assistance, which, in aggregate, allows, if not fully form, then at least ensure that the supervised persons demonstrate the law-abiding behaviour for the period of administrative supervision [18].

Administrative supervision functions. We draw our focus toward the etymology of the word "function". This word came to the Russian language from Latin, where "function" meant fulfillment. Russian dictionaries indicate the ambiguity of this word. However, of interest is the following meaning of the term under consideration, namely the role and/or meaning of something [19] taking into account that the function of administrative supervision 
should be understood as the key activities of the subjects carrying it out, which express the very essence and nature of that legal institution, as well as its purpose in the state and in society as a whole. Thus, the functions of administrative supervision more clearly demonstrate its real role, which it plays in solving the problems of crime prevention in the state.

The analysis of the legal doctrine and regulatory documents in the area under consideration allows us to conclude that the functions of administrative supervision are preventive function (private and general prevention); educational function; suppressive and regulatory function.

Currently, there is a need to improve the law No. 64-FZ in the context of the problems raised, and it is proposed to present Article 2 of this law in the wording as follows:

\section{Article 2. Purpose and objectives of administrative supervision}

1. Administrative supervision is established in order to prevent the commission of crimes and other offences by the persons specified in Article 3 of the federal law.

The objectives of administrative supervision are implementation by the internal affairs bodies of supervision over the observance by supervised persons of temporary restrictions on their rights and freedoms, as well as over the fulfilment by them of the duties provided for by the federal law; identification of violations by the supervised persons and taking measures in accordance with the law; individual preventive treatment of such persons.

\section{Conclusion}

Based on the foregoing, it should be stated that administrative supervision is an important and effective mechanism for preventing crime, and, as a consequence, solving the problems of reducing the level of recidivism.

Undoubtedly, within the framework of this article, far from all the problems of legislative regulation of the point at issue are considered. First of all, the authors tried to draw the attention of researchers and scientists and present their vision of the problem which requires further research.

\section{References}

1. M. Gregory, Tech. Soc. Sci. J. 16, 175-182 (2021). https://doi.org/10.47577/tssj.v16i1.2668

2. N. Demleitner, Fed. Senten. Rep. 33, 11-21 (2020). https://doi.org/10.1525/fsr.2020.33.1-2.11

3. S. Quattrocolo, Predictability of violent behaviour and recidivism, in Artificial Intelligence, Computational Modelling and Criminal Proceedings. Legal Studies in International, European and Comparative Criminal Law, vol. 4, 131-180 (Springer, Cham., 2020). https://doi.org/10.1007/978-3-030-52470-8_6

4. Hearings "Massachusetts Furlough Program" (Massachusetts House Post-Audit Committee, Oct. 21, 1987)

5. I.V. Dvoryanskov, Prevention of recidivism in institutions executing criminal punishments in the form of imprisonment, in I. Dolgova (ed.), Problems of Crime Determination and Prevention (Moscow, Russian Criminological Association, 2017)

6. V.G. Gromov, A.N. Galkina, Mod. Law 2, 115 (2015)

7. A.M. Rozuvan, N.S. Artemiev, Herald Vyatka State Univ. 1, 74 (2012)

8. Ch. Yarmaki, V. Yarmaki, Int. Acad. J. WoS 5(35), 55-58 (2019). https://doi.org/10.31435/rsglobal_wos/31052019/6506 
9. J. Moore, J. Eikenberry, Crime \& Delinq. 67(3) (2021). https://doi.org/10.1177/0011128720944075

10. J.-S. Gong, J.-H. Kim. Kor. Police Stud. Rev. 18, 25-58 (2019). https://doi.org/10.38084/2019.18.2.2

11. T.G. Ponyatovskaya, Act. Iss. Crime Prev.: Crim. J. Baikal National Univ. Econ. and Law 3, 100 (2013)

12. N.V. Temnikova, Preduprezhdenie prestupleniy podnadzornyh lits [Prevention of the Crimes of Supervised Persons], Abstract of PhD Thesis in Law (Moscow, 2015)

13. L. Lazarus, J. Blackbourn, Intelligence and the criminal law in England and Wales, in M. Dyson, B. Vogel (eds.), The Limits of Criminal Law: Anglo-German Concepts and Principles, 479-506 (Intersentia, 2020). https://doi.org/10.1017/9781780687988.024

14. V.P. Gutsulyak, A.M. Aloyan, I.P. Danilov, Administrative Supervision over Persons Released from Detention Facilities (Moscow, Research Institute of the Ministry of Internal Affairs of the Russian Federation, 2002)

15. V.G. Gromov, A.N. Galkina, Modern Law, 6, 24 (2015)

16. S.Ya. Podoprigora, A.S. Podoprigora (eds.), Philosophical dictionary (Rostov-on-Don, Fenix, 2010)

17. A.M. Prokhorov (ed.), Soviet encyclopedic dictionary (Moscow, 1985)

18. E.V. Kashkina, Bul. Kazan Law Inst. MIA Russia 1(27), 34 (2017)

19. S.I. Ozhegov, Dictionary of the Russian language (Moscow, Peace and Education, 2015) 